\title{
Learning Design for Topic Two Variable Linear Equation Systems for Students of Machinery and Automotive Engineering Techniques Programs at Vocational High School
}

\author{
Armiati $^{1}$, Roli Mazendra ${ }^{2}$ \\ \{rolimaizendra10@gmail.com² \\ Mathematics and Science Faculty, Universitas Negeri Padang, Indonesia 1,2
}

\begin{abstract}
This paper discusses the importance of designing mathematics learning for technology vocational school students. The two-variable linear equation system is one of the topics taught to students in vocational schools. Learning the topic of two-variable linear equation systems has been designed by linking problems to the mechanical and automotive engineering expertise program. This is done so students are aware of learning mathematics needs, especially SPLDV material. This learning design has been developed through a research development involving 42 students from SMK 1 Padang. Data were collected through observation, interviews, field notes and analysis of test results. The results of this study indicating the SPLDV learning design linking problems to the mechanical and automotive engineering expertise program can help students develop their problem mathematics skills. Through this research, it is also known that this learning design has also been able to increase the interest of vocational school students towards mathematics.
\end{abstract}

Keywords: Learning Design, Mathematics Communication, Two-Variable Linear Equation Systems, Vocational High School

\section{Introduction}

Vocational schools are formal educational institutions whose aim is to prepare students to work immediately after completing their education. This is stated in government regulation No. 20 of 2003 article 15 which states that "Vocational education is secondary education that prepares students primarily to work in certain fields" [1]. But in reality in recent years vocational school students are the biggest contributor to unemployment. Based on data from the Central Statistics Agency (BPS) as of February 2019, the percentage of Open Unemployment Rate for vocational schools is the highest $8.63 \%$ compared to the others. This should be a concern of the government because this trend is repeated every year [2].

In order to compete in the world of work, there are at least ten skills that must be possessed by every graduate of a vocational school. These skills are 1) Critical Thinking, 2) Communications, 3) Access, analyze, synthesize information, 4) Creative and innovative, 5) Leadership, 6) ability to adaptts, 7) Collaborations with the other, 8) Public speaking, 9 ) Time management, 10) Networking, [3]. All of these skills can actually be trained through learning mathematics. Because all of these skills correspond to the learning objectives of the Jama'at in high school. 
In order to be able to practice all of these skills, designed learning should facilitate students to be directly involved in the learning process. The two-variable linear equation system (SPLDV) is one of the topics in mathematics taught in vocational schools. Several studies [3], [4], [5], mention students often have difficulty in understanding problems related to SPLDV. According to research that has been done, the difficulties experienced by vocational school students in completing SPLDV are difficulty understanding symbols, difficulties in the process, and difficulties in calculation [3]. Problems in SPLDV are often presented in the form of contextual problems. Difficulties in symbols can occur because in SPLDV learning, it often starts by giving a general form of SPLDV. Figure 1 is showing how to deliver SPLDV material contained in vocational school mathematics textbooks [4].

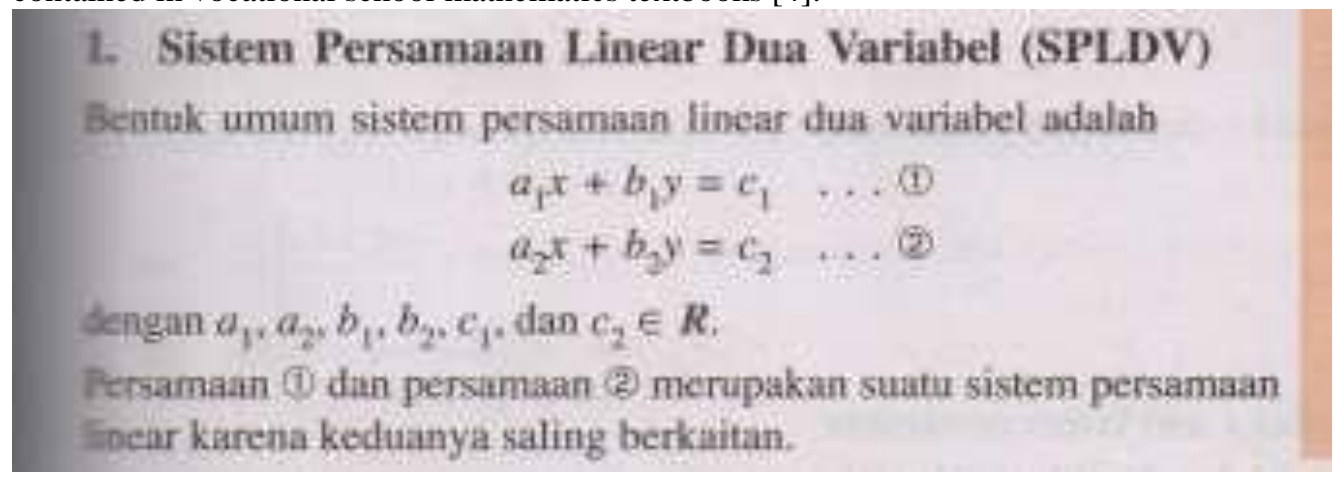

Fig. 1. Presentation of SPLDV in the SMK mathematics textbooks.

This form is not meaningful for students, so when faced with real context problems, students have difficulty turning these problems into mathematical symbols. The presentation only requires students to memorize, whereas in the vocational field students are often faced with problems that cannot be solved by memorization. Memorized learning will not be able to practice the abilities demanded by the world of work. Based on the vocational school mathematics textbooks [4] the training presentation for SPLDV material is shown in Figure 2.

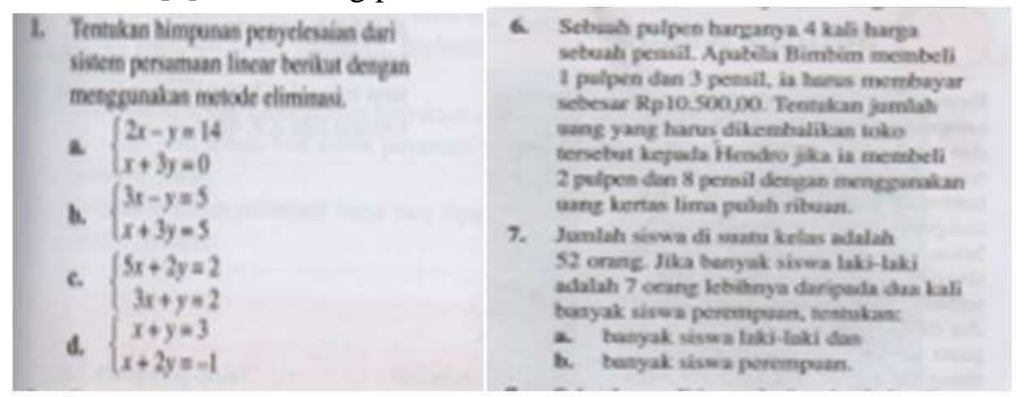

Fig. 2. Training presentation for SPLDV material.

It appears that the questions given are too general not related to the existing expertise program in vocational schools. This is the reason why students do not like mathematics, because they do not see the benefits of learning mathematics for their expertise program [5] [6]. Some studies mention that students' mathematical problem solving ability is a problem that needs attention [7], [8], [9], and is classified as a very poor condition in mathematics learning [10], [11], [12]. Some studies suggest that the problem-solving ability is an ability that still requires 
attention, because this ability is still relatively low. For this reason, it is necessary to design learning that will develop the various skills needed to enter the workforce and increase vocational school students' interest in mathematics.

\section{Research Methods}

This study uses a development research plan from Plomp which consists of three stages [13]. The Plom model was chosen, because in the development of SPLDV topic learning design begins with gathering initial information related to existing SPLDV learning design and implemented in vocational schools. Subsequently an assessment was made of the linkages of SPLDV material with subjects of mechanical and automotive engineering expertise programs. These two activities are included in the preliminary research stage of the Plomp model [13]. The next stage is the development of learning design, which refers to the results of the preliminary stage.

The SPLDV learning design begins by raising issues related to the mechanical and automotive engineering expertise program. In this design students are guided to discover the SPLDV concept, by asking questions (scaffolding). Furthermore, the design results were tested in two stages. In the small group stage, 9 class X students of SMK 1 Padang Indonesia were involved, and 32 class X students from the same school were involved in the field test stage. Through research also examined the impact of this design on the problem-solving abilities of class X students of the mechanical engineering skills program that was the research sample.

\section{Results and Discussion}

The SPLDV learning plan was validated to three mathematics education experts before being tested. The results shown are, the SPLDV learning design meets valid criteria [14], with the proposed contextual problem characteristics closely related to the daily problems of students in mechanical and automotive engineering expertise programs, this can trigger student interest in trying to solve problems. Activities in the design are arranged systematically so that it can lead students to find the SPLDV concept. The steps in the learning design allow students to develop problem solving abilities [15]. At the end of the learning steps students are given exercises related to the expertise program and also the general form of SPLDV as contained in vocational school mathematics books in general.

The SPLDV learning design is also categorized as practical, students can understand the problems posed because they are close to their happiness, the steps that are designed make it easier for students to carry out activities to get the SPLDV concept. The time provided for students to solve each problem in this design is clearly specified. Figure 3, is an example of a problem given to direct students to get the general form of SPLDV. This issue is directly related to the topics in the mechanical and automotive engineering expertise program. 


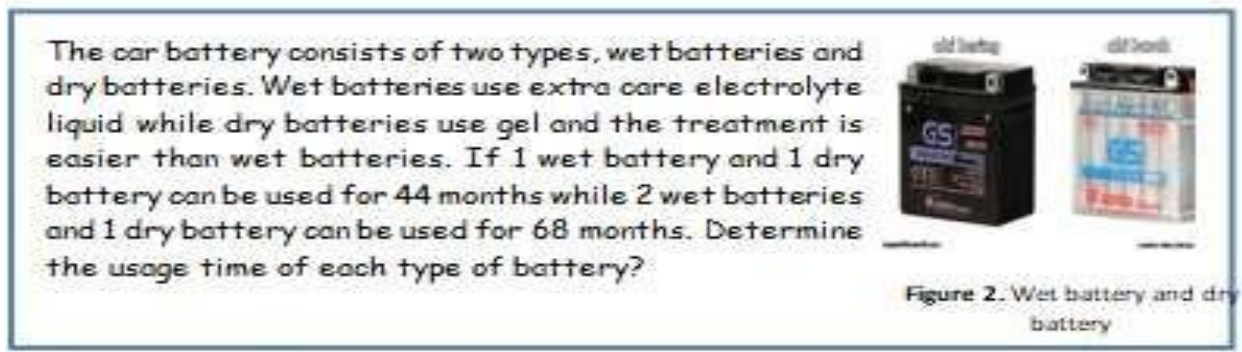

1. What information is abtained from the problem above?

Fig. 3. Examples of mechanical engineering problems to understand the SPLDV concept.

Based on these problems students are guided through questions that will lead them to the SPLDV concept. Figure 4 is an example of students' answers in finding the general form of SPLDV.

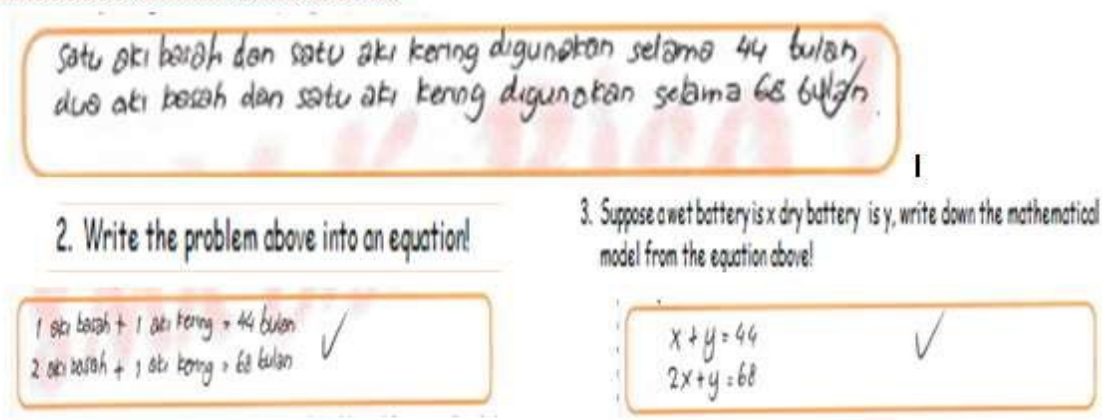

4. Write doun the problems that must be solved from the problem abovel

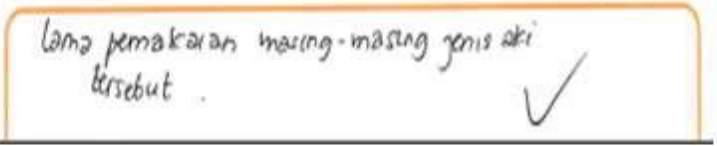

Fig. 4. Examples of students' answers in finding the SPLDV concept.

Based on the students' answers, it appears that the activity designed has led students to understand problems, change problems into mathematical models, and understand what needs to be solved in those problems. This will train students' problem solving skills. Through discussion activities, students were also enthusiastic in learning mathematics. Figure 5 below presents the problems given after students understand the SPLDV concept. 


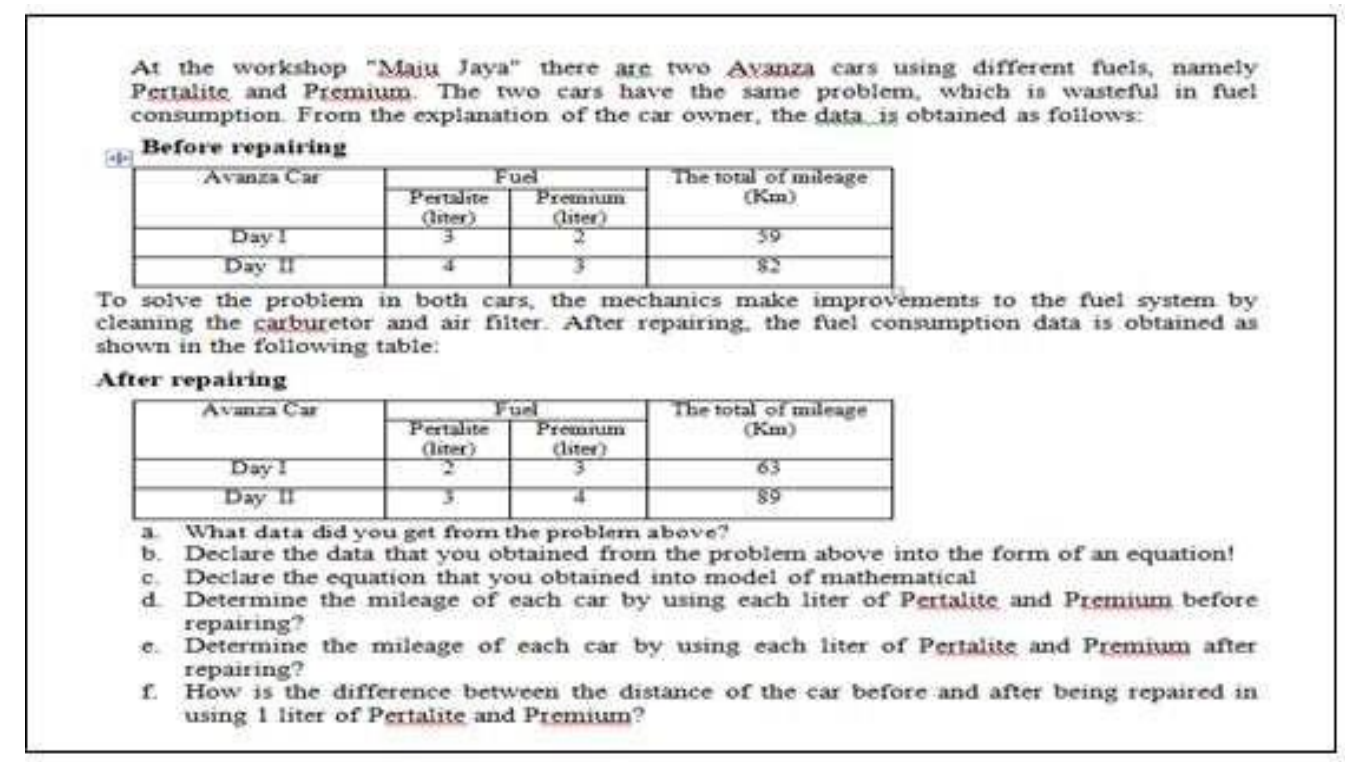

Fig. 5. Example of contextual problems related to SPLDV.

In this section students are given the opportunity to solve these problems by answering several referral questions. One example of student answers is shown in Figure 6 below.
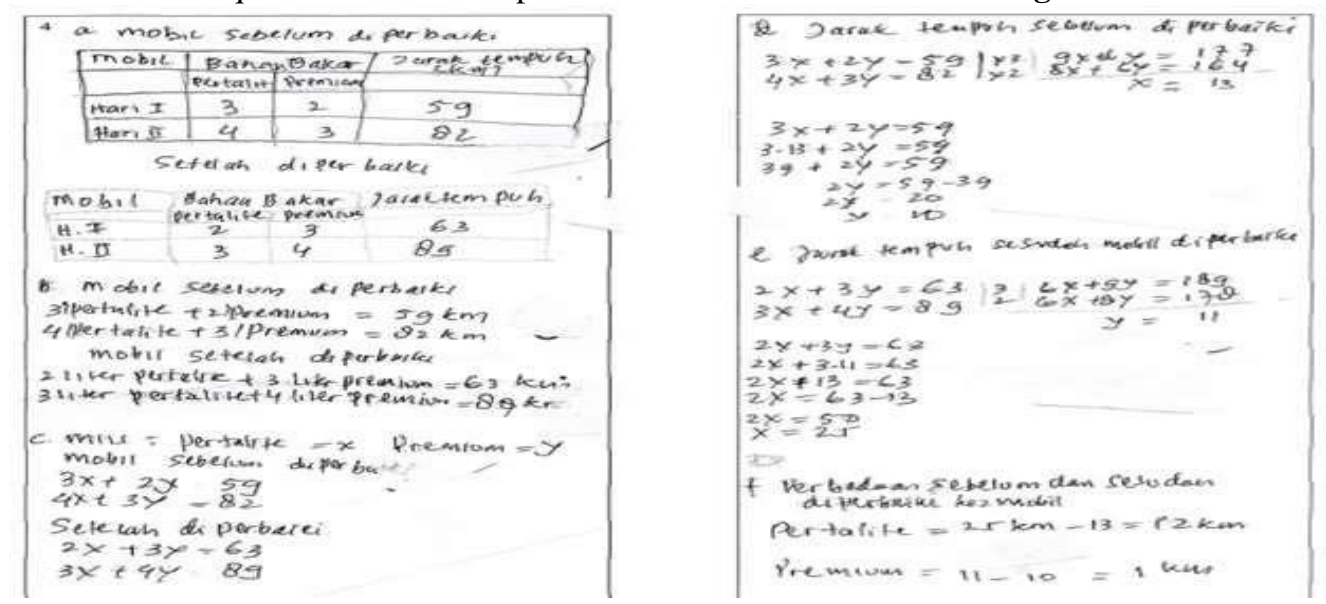

Fig. 6. Examples of student answers related to the contextual problems of mechanical engineering.

Based on the answers given in Figure 6, students can change contextual problems into a table, which means they have understood the problem (the answer to question a). In part $b$, students demonstrate their ability to convert problems into the form of equations, meaning that they find a simple form of the problem given. In section c students make a mathematical model for the problem, this will lead him to find a solution strategy. In parts d and e, students use one of the strategies in problem solving. In part $\mathrm{f}$, students can return information from mathematical calculations that they get into solving real problems. These results indicate that 
the SPLDV learning design that has been developed has the potential to improve the problemsolving abilities of vocational school students. Based on observations during the course of the study it was also known that the problems associated with vocational school student expertise programs could motivate students to learn mathematics.

Through experiments it is known that the average problem solving ability test of students who learn to use the SPLDV learning design that is designed better than the average problem solving ability test of students who learn conventionally. In the experimental class there were $73.13 \%$ of students who were classified as complete, while students in control class only $33 \%$ were complete. These results indicate that the SPLDV learning design that has been developed through this research has effectively achieved the objectives formulated at the beginning of the study.

\section{Conclusions}

The learning design for the SPLDV topic uses problems based on vocational school expertise programs developed in this study that have met the valid, practical and effective criteria. This research uses research design from Plomp, this design is proven to help the achievement of research objectives. The SPLDV learning design can be used in teaching SPLDV in mechanical engineering and automotive engineering programs. So far the SPLDV learning design that has been developed can help improve the problem solving skills of vocational school students, and foster their motivation to learn mathematics.

\section{References}

[1] Republic of Indonesia Law No. 20 of 2003 concerning the National Education System (2003)

[2] Suhariyanto.: CNN Indonesia on Monday, 06/05/2019 12:59 WIB Head of BPS Suhariyanto (2019)

[3] Rahayuningsih, P., Abdul, Q.: Analisis Kesalahan menyelesaikan soal cerita SPLDV dan Scafoldingnya berdasarkan Analisis Kesalahan Newman pada Siswa Kelas VII SMPN 2 Malang. Science and Mathematics Education Journal. Tahun II No 2, (2014)

[4] Akbar, H., Sari., Andika, V.T.: Analisis Kesalahan Siswa Dalam Menyelesaikan Soal Sistem Persamaan Linear Dua Variabel Pada Siswa Kelas Viii Mts Di Kabupaten Bandung Barat. Journal On Education. Vol. 01, No. 02. pp.15-22. E-ISSN 2654-5497 P-ISSN 2655-1365 (2014)

[5] Armiati., La'ia., Tansil., Hestu.: The Developed Mathematics Learning Tools Which Based on Professional Competency In The Phase of One to One Evaluation For Trigonometry Topic In The Major of Information and Communication Engineering of SMK. Atlantis Press Advances in Social Science, Education and Humanities Research (ASSEHR), volume 285. 2nd International Conference on Mathematics and Mathematics Education 2018 (2018)

[6] Armiati.: Mengembangkan Higher Order Thinking Skill Melalui Pembelajaran Matematika Pada Siswa Sekolah Menengah. LEMMA, Vol 4, No. 2, p-ISSN 2407-4527 E-ISSN 2460-1047. p 7-19 (2018)

[7] Rajotte., Thomas.: Evaluation of the Effect of Mathematical Routines on the Development of Skills in Mathematical Problem Solving and School Motivation of Primary School Students in AbitibiTémiscamingue. Jurnal: Universal Journal of Educational Research Vol. 4(10), pp. 2374 - 2379 (2014) [8] Sangpom, W. Advanced Mathematical Thinking and Students' Mathematical Learning: Reflection from Students' Problem-Solving in Mathematics Classroom (2016)

[9] Özsoy G.: Evaluation of Students' Mathematical Problem Solving Skills in Relation to Their Reading Levels. Journal: International Electronic Journal of Elementary Education (2015) 
[10] Karatas, I., Baki, A.: The Effect of Learning Environments Based on Problem Solving on Students' Achievements of Problem Solving. Journal: International Electronic Journal of Elementary Education (2013)

[11] Masami, I.: Lesson Study: Problem Solving Approaches in Mathematics Education as a Japanese Experience. Journal: International Conference on Mathematics Education Research 2010 (2010)

[12] Mawaddah, S., Hana, A.: "Kemampuan Pemecahan Masalah Matematis Siswa pada Pembelajaran Matematika dengan Menggunakan Model Pembelajaran Generatif (Generatif Learning) di SMP”. EDUMAT Mathematics Education Journal, Vol. 3, No. 2. (2015)

[13] Plomp, T,. Nieveen. N.: Educational Design Research. Enshede: Netherlands Institute for Curriculum Development (SLO). (2013)

[14] Nieeven, N., Folmer, E.: Educational Design Research Part A: an Introduction Ed: T Plomp and N Nieveen (Enschede: SLO). pp. 152-169 (2013)

[15] Polya, G. How to Solve It: A New Aspect of Mathematical Method (Second ed.). Princeton , N.J.: Princeton Science Library Printing. (1973) 